\title{
Clinical and Molecular Study of the NOG Gene in Families with Mandibular Micrognathism
}

\author{
Sandra J. Gutiérrez-Prieto ${ }^{1}$ Diana M. Torres-López ${ }^{2}$ \\ Jorge A. Rey-Cubillos ${ }^{3}$ Mariluz Gómez-Rodríguez ${ }^{4}$ \\ 1Department of Dental System, Department of Oral System, \\ Center for Dental Research, School of Dentistry, Pontificia \\ Universidad Javeriana, Bogotá, Colombia \\ 2 Institute for Human Genetics, School of Medicine, Pontificia \\ Universidad Javeriana, Bogotá, Colombia \\ ${ }^{3}$ Postgraduate Department, School of Medicine, Universidad Militar \\ Nueva Granada, Bogotá, Colombia \\ ${ }^{4}$ Department of Natural Sciences and Mathematics, School of \\ Engineering and Sciences, Pontificia Universidad Javeriana Cali, \\ Cali, Colombia
}

Dabeiba A. García-Robayo ${ }^{1}$

Eur J Dent 2021;15:746-754.

\author{
Address for correspondence Sandra J. Gutiérrez-Prieto, Pontificia \\ Universidad Javeriana, School of Dentistry, Center for Dental \\ Research, 4th Floor, Carrera 7 \# 40-62 Bogotá 110211, Colombia \\ (e-mail: s.gutierrez@javeriana.edu.co).
}

\begin{abstract}
Keywords

- noggin gene

- mandibular micrognathism

- methylation

- bone morphogenic proteins

Objectives Previous studies showed that noggin gene (NOG) sequence alterations, as well as epigenetic factors, could influence mandibular development. The aim of this study was to analyze clinical characteristics, NOG gene sequences, and promoter methylation sites in patients with mandibular micrognathism.

Materials and Methods A total of 35 individuals of five Colombian families were subject to clinical and cephalometric analysis for mandibular micrognathism. One nonaffected individual of each family was included as a control. DNA was isolated from whole blood sample from all individuals by salting out method. Nine NOG gene fragments were amplified by polymerase chain reaction (PCR) and sequenced. Identification of CPG islands for methylation analysis at the NOG gene promoter was performed by MSP-PCR kit (Qiagen R).

Statistical Analysis A descriptive statistical analysis was carried out evaluating the presence or absence of genetics variants and the methylation sites in the NOG gene.

Results NOG sequence results of affected individuals with mandibular micrognathism for one of the families studied demonstrated that they were heterozygous for $672 \mathrm{C} / \mathrm{A}$ (new mutation). For a second family, individuals were heterozygous for $567 \mathrm{G} / \mathrm{C}$ (single nucleotide polymorphism [SNP] RS116716909). For DNA analyzed from all patients studied, no methylations were observed at the NOG gene promoter region.

Conclusion Our results suggested that $672 \mathrm{C} / \mathrm{A}$ and $567 \mathrm{G} / \mathrm{C}$ variants could be involved in the presence of mandibular micrognathism. Moreover, lack of methylation sites at the NOG gene promoter region of all individuals studied suggests possibly other epigenetic factors could modulate mandibular growth. The search of genetic variants related with mandibular micrognathism will allow to predict in an integral way the development patterns of the patients and therefore establish a better clinical treatment.
\end{abstract}

published online September 30, 2021
DOI https://doi.org/ $10.1055 / \mathrm{s}-0041-1726162$ ISSN 1305-7456.
(C) 2021. European Journal of Dentistry.

This is an open access article published by Thieme under the terms of the Creative Commons Attribution-NonDerivative-NonCommercial-License, permitting copying and reproduction so long as the original work is given appropriate credit. Contents may not be used for commercial purposes, or adapted, remixed, transformed or built upon. (https://creativecommons.org/licenses/by-nc-nd/4.0/)

Thieme Medical and Scientific Publishers Pvt. Ltd., A-12, 2nd Floor, Sector 2, Noida-201301 UP, India 


\section{Introduction}

One of the most frequent craniofacial malformations in the population is cleft palate and mandibular micrognathism, ${ }^{1,2}$ affecting the patients' quality of life. ${ }^{3}$ Mandibular micrognathism is characterized by the deficiency of mandible growth, which may be a cause of abnormal tooth alignment, not allowing for teeth to come in contact during mastication. Moreover, it interferes with the patient's phonation. In its severe form, micrognathism can be associated with sleep apnea ${ }^{4,5}$ and combined with glossoptosis and cleft palate (the isolated Pierre Robin sequence), it can obstruct the airways and thus result in difficulty of breathing. ${ }^{2}$ Its etiology seems to include genetic factors, such as environmental, which are not well understood. ${ }^{6}$

Various studies demonstrate mandibular processes are composed of two independent functional regions, two large lateral processes depending on fibroblast growth factor (FGF)-8 signaling for development, and a small medial region independent of FGF-8. Therefore, mandible morphogenesis is characterized by a unique pattern of signaling molecules including bone morphogenetic protein-4 (BMP-4) and FGF-8. ${ }^{7-10}$ Bone morphogenetic proteins contribute with the formation of mandible components, yet they are implicated in other developmental processes, such as neurogenesis, joint and bone formation, and apoptosis of mesenchymal cells, at the joint site for the formation of synovial joint cavities. ${ }^{11-15}$

This signaling pathway is regulated by various antagonists. Of these, the 232 amino acid (NP 005441) glycoprotein noggin, ${ }^{16}$ codified by the NOG gene located on chromosome 17q22 (NOG; MIM no.: 602991) that consists of a single 696 bp exon. ${ }^{17}$ Noggin modulates BMP signaling, preventing cell receptor binding, thus inhibiting signal transduction. By this mechanism, it modulates various signaling pathways during cartilage and bone formation in human development. ${ }^{16,17}$ NOG gene mutations results in BMP signaling alterations which leads to different types of dysplasias, such as proximal symphalangism (MIM 185800), which can be present with other phenotypic characteristic such as hemicylindrical nose configuration, hearing loss, as well as brachydactyly type 2 and synostosis type 1 (MIM 186500), among others. ${ }^{18-21}$

To date, some studies suggest NOG as a candidate for craniofacial disorders. A study performed in homozygous mice $\left(\mathrm{Nog}^{-1}\right)$ revealed the absence of mandible development, mandibular hypoplasia, micrognathism, and agnathia. This study suggested NOG could act as an etiological factor in holoprosencephaly where mandibular micrognathism was evident. ${ }^{22}$ Gutiérrez et $\mathrm{al}^{23}$ reported a possible association between 112 C > A (rs1348322) NOG exon 1 polymorphism with mandibular micrognathism in affected individuals in Colombian families. Likewise, significant associations have been identified between nonsyndromic cleft lip and palate and a single NOG nucleotide polymorphism (SNPs), suggesting that mutations in this gene could be relevant in mandible and palate development. ${ }^{24-27}$ Studies by Nimmagadda et $\mathrm{al}^{28}$ established peptidase inhibitor (PI)-15 expressed in the frontonasal process, acted synergistically with NOG to induce maxillary and mandible cartilage, in addition to dental germ formation. Studies other than genetic factors suggest that epigenetic factors contribute to BMP signaling, demonstrating it is possible to activate these signaling proteins through protein methylation via Smad6. ${ }^{28-30}$

The genotype-phenotype correlation of the NOG gene and mandibular micrognathism is still not very clear, and it is possible that there are also environmental factors that may be involved in its etiology. Therefore, the present work evaluated the presence of mutations in NOG gene in Colombian patients presenting mandibular micrognathism to establish a possible genotype-phenotype association and to carry out an initial exploration of the methylation sites in the promoter region of this gene to determine if there are possible epigenetic factors that may influence the etiology of this entity.

\section{Materials and Methods}

This project was approved by the ethics Committee School of Dentistry of the Pontificia Javeriana University (Minute 008 of 2011). The investigation was conducted in full accordance with ethical principles, including the World Medical Association Declaration of Helsinky (2002). The population included five families with 35 individuals: 16 affected with mandibular micrognathism and 19 nonaffected individuals. All patients were examined by a physician at the School of Dentistry of the Pontificia Javeriana University. Informed consent was read and signed after the project was explained to each participant. A clinical genetic examination was performed to determine other phenotypes associated with a syndromic condition. Additionally, family trees were performed to determine inheritance patterns. Oral cavity examination was conducted, as well as oral photographs (front, profile, and smile). Moreover, profile and lateral cranial X-rays were performed to trace cephalometric measurements on them and determine presence of mandibular micrognathism (-Table 1).

\section{DNA Extraction and Polymerase Chain Reaction Amplification}

A $10-\mathrm{mL}$ sample of peripheral blood was collected in Ethylenediaminetetraacetic (EDTA) tubes from each participant. DNA was extracted by salting out method ${ }^{31}$ and stored at $20^{\circ} \mathrm{C}$ before use. Nine fragments corresponding to 699 nucleotides NOG coding region, 437 nucleotides upstream, and 729 nucleotides downstream were amplified by polymerase chain reaction (PCR) using primers designed with PRIMER 3 program (http://primer3.sourceforge.net) - Table 2). For PCR reactions, a master mix with a total volume of $25 \mu \mathrm{\Lambda}$ was prepared, containing: $0.3 \mu \mathrm{L}$ Taq DNA polymerase (Promega $5 \mu / \mu \mathrm{L}$ ), $0.60 \mu \mathrm{L}$ of each primer, $0.75 \mu \mathrm{L}$ of dNTPs, $3 \mu \mathrm{L} \mathrm{MgCl}_{2}, 2.5 \mu \mathrm{L}$ of 10 X Buffer (Promega, Madison, Wisconsin, United States) and $1 \mu \mathrm{L}$ of DNA ( $50 \mathrm{ng} / \mu \mathrm{L})$. Reaction was set up under the following conditions: initial denaturation at $95^{\circ} \mathrm{C}$ for 10 minutes; 35 cycles of denaturation at $94^{\circ} \mathrm{C}$ for 45 seconds, annealing temperature for each primer (-Table 2), and an extension at $72^{\circ} \mathrm{C}$ for 45 seconds (Bio-Rad Thermocycler, California, United States). A final extension was performed at $72^{\circ} \mathrm{C}$ for 7 minutes. Amplification product was verified in $1.5 \%$ agarose gel using ethidium bromide. 
Table 1 Mandibular micrognathism cephalometric measurements for patient diagnosis

\begin{tabular}{|c|c|c|c|}
\hline Mandible size & $\begin{array}{l}\text { Distance }(\mathrm{mm}) \text { from condylion } \\
\text { (Co) to gnathion (Gn)-Bimler } \\
\text { Peter }\end{array}$ & $\begin{array}{l}\text { Distance }(\mathrm{mm}) \text { from gonion } \\
\text { (Go) to pogonion }(\mathrm{Pg}) \text {-Legan } \\
\text { and Burstone }\end{array}$ & $\begin{array}{l}\text { Distance }(\mathrm{mm}) \text { from point } \mathrm{Xi} \text { to } \\
\text { the point of intersection of line } \\
(\mathrm{Xi}-\mathrm{Pm}) \text { and }(\mathrm{A}-\mathrm{Pg})-\text { Ricketts } \\
\text { Robert }\end{array}$ \\
\hline $\begin{array}{l}\text { Mandible ramus } \\
\text { height }\end{array}$ & $\begin{array}{l}\text { Distance }(\mathrm{mm}) \text { from articular point } \\
(\mathrm{Ar}) \text { to Go point-Bimler Peter }\end{array}$ & $\begin{array}{l}\text { Distance }(\mathrm{mm}) \text { from Go point } \\
\text { to the horizontal line }(\mathrm{FH}) \text { on } \\
\text { the plane }(\mathrm{C}-\mathrm{Go}) \text {-Legan and } \\
\text { Burstone }\end{array}$ & $\begin{array}{l}\text { Distance }(\mathrm{mm}) \text { from CF to Go. Ricketts } \\
\text { Robert }\end{array}$ \\
\hline Maxillary ratios & $\begin{array}{l}\text { Effective mean length, effective man- } \\
\text { dibular length (table of compound } \\
\text { standards) ratio between maxillary } \\
\text { length and mandibular length (Co-A) } \\
\text { and (Co-Gn)-McNamara }\end{array}$ & $\begin{array}{l}\text { Maxillary length, mandibular } \\
\text { length. ratio between distance in } \\
\mathrm{mm}(\mathrm{Co}-\mathrm{A}) \text { and }(\mathrm{Co}-\mathrm{Gn})-\text {-Epker } \\
\text { and Fish }\end{array}$ & \\
\hline Chin size & $\begin{array}{l}\text { Distance }(\mathrm{mm}) \text { from the projection of } \\
\text { point } \mathrm{B} \text { to the tangent to Pg perpen- } \\
\text { dicular to plane (Go-M)-Legan and } \\
\text { Burstone }\end{array}$ & & \\
\hline
\end{tabular}

Table 2 NOG gene codifying region amplification primers

\begin{tabular}{|l|l|l|l|l|}
\hline Fragment & Forward primer & Reverse primer & Size & Annealing $\left.\mathbf{T}^{\circ} \mathrm{C}\right)$ \\
\hline 1 & CCCCAGCCTAGGGGTCAC & GTACAGCACGGGGCAGAAT & 465 & 68 \\
\hline 2 & GCGAGATCAAAGGGCTAGAG & ATGGGGTACTGGATGGGAAT & 319 & 59 \\
\hline 3 & GTCCAAGTCCGTGCACCT & GAAGCCGGTAACTTTTAACGTA & 394 & 59 \\
\hline 4 & CTGTGTAGGAATGTATATGTGTGTG & TCCTGCTCTGCACTTCTTTC & 483 & 62 \\
\hline 5 & TTCTGGTTCCTGTAATGCACTG & CCCATCAATCACCAACACAG & 399 & 62 \\
\hline 6 & GACCTCCGGCGGGTC & TTCTAGGGGCACTTCCCTC & 450 & 64 \\
\hline 7 & CAGGACCACCACCAGGG & 220 & 64 \\
\hline 8 & CCCCAGCCTAGGGGTCAC & TGTAACTTCCTCCGCAGCTT & 426 & 59 \\
\hline 9 & GTGGGCAGCTGCTTCAGTA & GCGAAGGGCACTGGAATA & 570 & 59 \\
\hline
\end{tabular}

Abbreviation: NOG, noggin gene.

Table 3 NOG gene primers for methylation

\begin{tabular}{|l|l|l|}
\hline NOG gene & Primer forward & Primer reverse \\
\hline Methylated & 5' GGTTAGGGGAGTCGTAGGC 3' & 5“'CTCGAACCCACGAAAAAATT3' \\
\hline Non Methyl & 5' GGGTTAGGGGAGTTGTAGGT 3' & 5'CCTCAAACCCACAAAAAAATT3' \\
\hline Methylated 1 & 5' TATAGCGGGTTAGTAGAGGGC3' & 5“'CCTCAAAAACGCGACTAACT3' \\
\hline Non Methyl 1 & 5'GTTTATAGTGGGTTAGTAGAGGG3 & 5'AACCTCAAAAACACAACTAACTC3 \\
\hline
\end{tabular}

Abbreviation: NOG, noggin gene.

\section{Sequencing}

Amplified products were purified using a Wizard DNA purification system (Promega [Madison, Wisconsin, USA]), following the manufacturer's instructions. Furthermore, to establish the presence of mutations direct sequencing was performed in both directions. Sequencing was performed with ABI PRISM 310 automatic sequencer (Applied Biosystems, California, United States).

\section{Methylation Analysis}

DNA methylation was characterized according to identified CpG islands at NOG promoter region as reported in NCBI database. MSP-PCR (Qiagen, Verlon, the Netherlands) kit was used with primers designed with METHYL PRIMER EXPRESS software (-Table 3 ). A master mix with a total volume of $15 \mu \mathrm{L}$ contained $0.2 \mu \mathrm{L}$ amplitaq (Promega $5 \mathrm{u} / \mu \mathrm{L}$ ), $0.40 \mu \mathrm{L}$ of each primer, $0.50 \mu \mathrm{L}$ of dNTPs, $1.8 \mu \mathrm{L} \mathrm{MgCl}_{2}, 1.5 \mu \mathrm{L}$ buffer (Promega), and $1 \mu \mathrm{L}$ of DNA (50 ng/ $\mathrm{LL})$. Amplification conditions were initial denaturation at $95^{\circ} \mathrm{C}$ for 10 minutes; 35 cycles of denaturation at $94^{\circ} \mathrm{C}$ for 45 seconds, annealing temperature for each primer, and an extension at $72^{\circ} \mathrm{C}$ for 45 seconds (BioRad Thermocycler). A final extension was performed at $72^{\circ} \mathrm{C}$ for 7 minutes. The amplification product was verified in $1.5 \%$ agarose gel using ethidium bromide. 


\section{Results}

\section{Clinical Analysis}

Out of 35 individuals from five different families, 16 were diagnosed with mandibular micrognathism. Patients from each family revealed similar characteristics with regard to class-II molar relationship, retrognathia position, maxillary shape, and length and hypodivergent skeletal pattern. Convex profile was the most common, as well as overjet increased. Upon clinical-genetic examination, none of the affected individuals examined manifested joint discomfort, bone, or finger abnormalities, as well as any syndromic alteration. A total of seven individuals, belonging to two families studied (family 1 and family 2) presented mutations in the NOG gene. The genealogical trees of both families suggested an autosomic dominant pattern of inheritance (-Figs. 1 and 2 ). Proband frontal and profile photographs from each of the two families displayed similar characteristics, despite belonging to different families and be of a different sex. Likewise, they presented similarities between their cephalometric measurements such as normal mandibular body length (Go-Pg), skeletal class II, decreased mandible, decreased posterior cranial base, increased anterior cranial base, retruded pogonion among others. The resulting cephalometric measurements $\mathrm{Xi}-\mathrm{Pm} / \mathrm{Pg}$ (mandibular size-Ricketts) and Co-Gn (mandibular length-MacNamara), of the affected individuals of both families were decreased confirming the diagnosis of mandibular micrognathism ( - Tables 4 and $\mathbf{5}$ ).

\section{Molecular Analysis}

NOG Gene Sequence Variants and DNA Methylation

Results of noggin sequence (nine fragments) revealed that affected individuals with mandibular micrognathism belonged to family 1 and were heterozygous with a 672 C/A (new mutation) in NOG gene coding region ( - Fig. 3A). Moreover, the affected individuals with mandibular micrognathism belonging to family 2 presented a heterozygous variant in NOG gene corresponding to 567 G/C 3' UTR (SNP RS116716909), previously reported by Zody et al ${ }^{32}$ (-Fig. 3B). Furthermore, all individuals analyzed for DNA methylation at NOG gene promotor lacked $\mathrm{CH}_{3}$ group.

\section{Discussion}

The most identified mutations in exon 1 of NOG gene have been frequently associated with phenotypes, such as proximal symphalangism (SYM1; MIM no.: 185800) and other clinical spectra. ${ }^{18-21,33-38}$ Likewise, other studies have suggested the involvement of NOG gene in craniofacial disorders; including one performed in mice (NOG-/-) which showed different phenotypes that range from hypertrophy to total lack of mandible or agnathia where micrognathism is somewhere in between. ${ }^{22}$

In a previous study, we found a polymorphism reported in the National Center for Biotechnology Information (NCBI) SNP database and Ensembl (www.ncbi.nlm.nih.gov) in the NOG gene in Colombian patients with mandibular micrognathism, as an approximation of the possible role of this gene in this malformation..$^{23}$ In the present study, two changes were identified; a new variant reported here (de novo mutation), consisting of a change from a cytosine to an adenine at nucleotide 672 (c.672C > A) in the coding region of the NOG gene ( - Fig. 3A), and another reported in the literature corresponding to a change from guanine to a cytosine at nucleotide 567 (c.567G > C [rs116716909] ${ }^{32}$; ( - Fig. 3B). The variant c.567G $>$ C ( $\mathrm{r}$ s116716909), reported by Zody et $\mathrm{al}^{32}$ was identified in the 3' untranslated region (3'UTR) 567 nucleotides downstream of the stop codon. Until now, it had not been associated with any pathology nor with phenotypic characteristics since this variant was found in asymptomatic patients and no information is available in this regard. ${ }^{18}$

We found this polymorphic variant in a heterozygous form in individuals affected with mandibular micrognathism, belonging to one of the five families studied (family 2). This is the first time to report a possible association between this variant and mandibular micrognathism and its phenotypic characteristics are described ( - Table 5 ). The results suggest that the region where this mutation is located doesn't generate severe phenotypes but could be altering NOG binding to BMP receptors. Therefore, inadequate signaling could be related to affected neural crest cell migration and proliferation, resulting possibly in mandibular

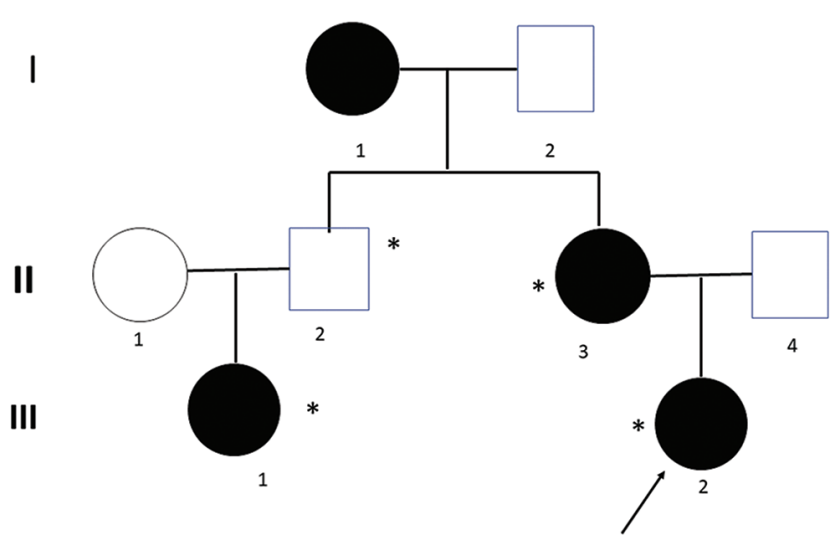

Fig. 1 Family 1. Genealogic tree suggested an autosomic dominant patterns (due the presence of a de novo mutation). Out of four individuals studied $\left({ }^{*}\right)$ in this family, three were affected by mandibular micrognathism. Patient III-2 corresponded to the proband (black arrow), patient II-3 to her mother, and the patient III. 1 corresponded to the cousin also affected. The uncle (II-2) was the control used.

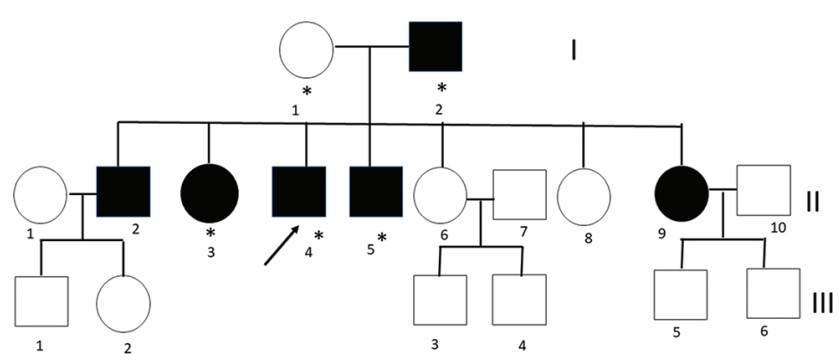

Fig. 2 Family 2. Genealogic tree shows autosomic dominant patterns. In this family four out of five individuals studied $\left({ }^{*}\right)$ were affected by mandibular micrognathism. Individual II-4 correspond to the proband (black arrow), patient I-1 to her mother, (health control). 
Table 4 Cephalometric measurements of individuals diagnosed with mandibular micrognathism belonging to family 1 where a new variant $672 \mathrm{C} / \mathrm{A}$ in the NOG gene was found

\begin{tabular}{|c|c|c|c|c|}
\hline Cephalometric measurement & Normal value (mm) & $\begin{array}{l}\text { Individual /value } \\
\text { III:2-F1 } \\
\text { (proband-affected) }\end{array}$ & $\begin{array}{l}\text { Individual /value } \\
\text { II:3-F1 (affected) }\end{array}$ & $\begin{array}{l}\text { Individual /value } \\
\text { III:1-F1 (affected) }\end{array}$ \\
\hline Go-Po (mm) & $\begin{array}{l}\mathrm{H}: 83.7 \pm 4.6 \\
\mathrm{M}: 74.3 \pm 5.8\end{array}$ & 78 & 74 & 78 \\
\hline $\begin{array}{l}\text { Xi-Pm/Pg } \\
\text { Mandibular micrognathism according to } \\
\text { McNamara cephalometry (mm) }\end{array}$ & $81 \pm 2.7$ & 74 & 73 & 74 \\
\hline Ar-Go (mm) & $\begin{array}{l}H: 52 \pm 4.2 \\
M: 46.8 \pm 2.5\end{array}$ & 35 & 48 & 55 \\
\hline CF-Go (mm) & $62 \pm 3.3$ & 62 & 60 & 76 \\
\hline Co-A (mm) & $\begin{array}{l}\mathrm{H}: 99.8 \pm 4.3 \\
\mathrm{M}: 91 \pm 6\end{array}$ & 91 & 90 & 96 \\
\hline $\begin{array}{l}\text { Co-Gn } \\
\text { Mandibular micrognathism according to } \\
\text { McNamara cephalometry (mm) }\end{array}$ & $\begin{array}{l}H: 132.3 \pm 6.8 \\
M: 120.2 \pm 5.3\end{array}$ & 114 & 112 & 114 \\
\hline Co-A/Co-Gn (mm) & $\begin{array}{l}H: 132.3 \pm 6.8 \\
M: 120.2 \pm 5.3\end{array}$ & 22 & 22 & 22 \\
\hline B_I PM/Pg (mm) & $\begin{array}{l}\mathrm{H}: 8.9 \pm 1.7 \\
\mathrm{M}: 7.2 \pm 1.9\end{array}$ & 7 & 7 & 5 \\
\hline Posterior skull base (mm) & $\begin{array}{l}H: 52.8 \pm 4.1 \\
M: 50.9 \pm 3.0\end{array}$ & 35 & 29 & 38 \\
\hline Anterior skull base (mm) & $\begin{array}{l}\mathrm{H}: 37.1 \pm 2.8 \\
\mathrm{M}: 32.8 \pm 1.9\end{array}$ & 53 & 51 & 51 \\
\hline Ba-Na/Ptm (degree) & $\begin{array}{l}\mathrm{H}: 90 \pm 3.5 \\
\mathrm{M}: 90 \pm 3.2\end{array}$ & 106 & 90 & 95 \\
\hline Sn-Pm (degree) & 32 & 52 & 33 & 33 \\
\hline GI-Sn-Pog (degree) & $12 \pm 4$ & 24 & 25 & 19 \\
\hline $\mathrm{Gl}(\mathrm{PH})-\mathrm{Sn}(\mathrm{mm})$ & $6 \pm 3$ & 0 & 1 & 3 \\
\hline $\mathrm{Gl}(\mathrm{PH})-\mathrm{Pog}(\mathrm{mm})$ & $0 \pm 4$ & 2 & 2 & 13 \\
\hline Gl-Sn/Sn-Me & 101 & 80.83 & $72: 65$ & 66.81 \\
\hline Nasolabial (Cm-Sn-Ls) in degree & $102 \pm 8$ & 108 & 98 & 109 \\
\hline Ls: Sn-Pog (mm) & $3 \pm 21$ & 7 & 3 & 7 \\
\hline Li: Sn-Pog (mm) & $2 \pm 21$ & 8 & 0 & 8 \\
\hline S. mentolabial (mm) & $4 \pm 22$ & 4 & 2 & 4 \\
\hline Sn-STMs/STMi-Me & 1:02 & 20:46:00 & 24:41:00 & 26:54:00 \\
\hline LE sup & $4 \mathrm{~mm} \mathrm{n} \pm 2$ & $2 \mathrm{~mm}$ & $2 \mathrm{mmn}$ & $3 \mathrm{~mm}$ \\
\hline LE inf & $2 \mathrm{mmn} \pm 2$ & $5 \mathrm{~mm}$ & $3 \mathrm{mmn}$ & $5 \mathrm{~mm}$ \\
\hline Facial morphological index & & Leptoprosope & leptoprosope & Leptoprosope \\
\hline Middle line facial symmetry & & Asymmetry & Symmetry & Symmetry \\
\hline Lip competition & & Lip incompetence & Lip competence & Lip competence \\
\hline Upper arch shape & & Triangular & Oval & Oval \\
\hline Lower arch shape & & Oval & Oval & Oval \\
\hline
\end{tabular}

Abbreviations: Ar, articular; Co, condylion; $\mathrm{Gn}$, gnathion; Go, gonion; NOG, noggin gene; Pg, pogonion; $\mathrm{Xi}$, center point of the ascendig ramus of the mandible; Pm, chin bulge point; CF, center point of the face; Sn, subnasal; G, glabela; PH, horizontal plane; I, incisor; Ba, basion; Me, menton; Li, labrale inferior; Ls, labrale superios; STMs, stomion- upper maxillary (superior); STMi, stomion-lower maxillary (inferior); S, sella; LE sup-LE inf: (mm), line that goes from the tip of the nose to the (Me) point should be paralell to the upper and lower lip.

micrognathism. This variant seems to alter one of the cysteines at the position 192, an amino acid that has been shown to be necessary for NOG to fulfill its biological activities, such its binding to BMPs receptors through the formation of disulfide bonds or possible hydrogen bonds with other amino acids. ${ }^{36}$
Even though various genetic association studies and chromosome 17 mapping of regions q22-q23, point out NOG as a gene that can be involved in various disorders, such as cleft-lip-palate ${ }^{24},{ }^{25}$ and height alterations in humans, ${ }^{27}$ none of these associated pathologies were observed in these 
Table 5 Cephalometric measurements of individuals diagnosed with mandibular micrognathism belonging to family 2 where a reported variant c.567G > C (rs116716909) in the NOG gene was found

\begin{tabular}{|c|c|c|c|c|c|}
\hline Cephalometric measurement & $\begin{array}{l}\text { Normal value } \\
(\mathrm{mm})\end{array}$ & $\begin{array}{l}\text { Individual/ } \\
\text { value II:4-F2 } \\
\text { (proband-affected) }\end{array}$ & $\begin{array}{l}\text { Individual/ } \\
\text { valuel:2-F2 } \\
\text { (affected) }\end{array}$ & $\begin{array}{l}\text { Individual/ } \\
\text { valuell:5-F2 } \\
\text { (affected) }\end{array}$ & $\begin{array}{l}\text { Individual/ } \\
\text { valuell:3-F2 } \\
\text { (affected) }\end{array}$ \\
\hline Go-Po (mm) & $\begin{array}{l}\mathrm{H}: 83.7 \pm 4.6 \\
\mathrm{M}: 74.3 \pm 5.8\end{array}$ & 76 & 73 & 76 & 75 \\
\hline $\begin{array}{l}\text { Xi-Pm/Pg } \\
\text { Mandibular micrognathism } \\
\text { according to McNamara } \\
\text { cephalometry }(\mathrm{mm})\end{array}$ & $81 \pm 2.7$ & 77 & 77 & 77 & 73 \\
\hline $\operatorname{Ar}-\mathrm{Go}(\mathrm{mm})$ & $\begin{array}{l}\mathrm{H}: 52 \pm 4.2 \\
\mathrm{M}: 46.8 \pm 2.5\end{array}$ & 54 & 52 & 48 & 44 \\
\hline CF-Go (mm) & $62 \pm 3.3$ & 63 & 73 & 62 & 57 \\
\hline Co-A (mm) & $\begin{array}{l}\mathrm{H}: 99.8 \pm 4.3 \\
\mathrm{M}: 91 \pm 6\end{array}$ & 98 & 99 & 94 & 83 \\
\hline $\begin{array}{l}\text { Co-Gn } \\
\text { Mandibular micrognathism } \\
\text { according to McNamara } \\
\text { cephalometry (mm) }\end{array}$ & $\begin{array}{l}H: 132.3 \pm 6.8 \\
M: 120.2 \pm 5.3\end{array}$ & 120 & 126 & 118 & 110 \\
\hline Co-A/Co-Gn (mm) & $\begin{array}{l}\mathrm{H}: 132.3 \pm 6.8 \\
\mathrm{M}: 120.2 \pm 5.3\end{array}$ & 22 & 27 & 24 & 27 \\
\hline B_I PM/Pg (mm) & $\begin{array}{l}\mathrm{H}: 8.9 \pm 1.7 \\
\mathrm{M}: 7.2 \pm 1.9\end{array}$ & 5 & 7 & 6 & 7 \\
\hline Posterior skull base (mm) & $\begin{array}{l}H: 52.8 \pm 4.1 \\
M: 50.9 \pm 3.0\end{array}$ & 37 & 40 & 35 & 32 \\
\hline Anterior skull base (mm) & $\begin{array}{l}\mathrm{H}: 37.1 \pm 2.8 \\
\mathrm{M}: 32.8 \pm 1.9\end{array}$ & 53 & 49 & 55 & 45 \\
\hline Ba-Na/Ptm (degree) & $\begin{array}{l}\mathrm{H}: 90 \pm 3.5 \\
\mathrm{M}: 90 \pm 3.2\end{array}$ & 92 & 103 & 93 & 97 \\
\hline Sn-Pm (degree) & 32 & 35 & 43 & 42 & 42 \\
\hline GI-Sn-Pog (degree) & $12 \pm 4$ & 22 & 20 & 26 & 30 \\
\hline $\mathrm{Gl}(\mathrm{PH})-\mathrm{Sn}(\mathrm{mm})$ & $6 \pm 3$ & 7 & 4 & 4 & 6 \\
\hline $\mathrm{Gl}(\mathrm{PH})-\mathrm{Pog}(\mathrm{mm})$ & $0 \pm 4$ & 4 & 13 & 12 & 1 \\
\hline Gl-Sn/Sn-Me & 101 & 75.68 & $78: 74$ & 79.75 & 59.65 \\
\hline Nasolabial (Cm-Sn-Ls) in ${ }^{\circ} \mathrm{C}$ & $102 \pm 8$ & 98 & 87 & 83 & 70 \\
\hline Ls: Sn-Pog (mm) & $3 \pm 21$ & 7 & 7 & 8 & 8 \\
\hline Li: Sn-Pog (mm) & $2 \pm 21$ & 7 & 7 & 5 & 7 \\
\hline S. mentolabial (mm) & $4 \pm 22$ & 4 & 4 & 4 & 6 \\
\hline Sn-STMs/STMi-Me & $1: 02$ & 23:45:00 & $28: 47: 00$ & 24:50:00 & 21:44:00 \\
\hline LE sup & $4 \mathrm{~mm} \mathrm{n} \pm 2$ & $1 \mathrm{~mm}$ & $1 \mathrm{mmn}$ & $1 \mathrm{~mm}$ & $0 \mathrm{~mm}$ \\
\hline LE inf & $2 \mathrm{mmn} \pm 2$ & $3 \mathrm{~mm}$ & $2 \mathrm{mmn}$ & $0 \mathrm{~mm}$ & $1 \mathrm{~mm}$ \\
\hline Facial morphological index & & Leptoprosope & leptoprosope & Leptoprosope & Leptoprosope \\
\hline Middle line facial symmetry & & Asymmetry & Asymmetry & Symmetry & Symmetry \\
\hline Lip competition & & Lip competence & $\begin{array}{l}\text { Lip } \\
\text { competence }\end{array}$ & $\begin{array}{l}\text { Lip } \\
\text { competence }\end{array}$ & Lip competence \\
\hline Upper arch shape & & Oval & square & Oval & Oval \\
\hline Lower arch shape & & Oval & Oval & Oval & Oval \\
\hline
\end{tabular}

Abbreviations: Ar, articular; Co, condylion; Gn, gnathion; Go, gonion; NOG, noggin gene; Pg, pogonion; Xi, center point of the ascendig ramus of the mandible; Pm, chin bulge point; CF, center point of the face; Sn, subnasal; G, glabela; PH, horizontal plane; I, incisor; Ba, basion; Me, menton; Li, labrale inferior; Ls, labrale superios; STMs, stomion- upper maxillary (superior); STMi, stomion-lower maxillary (inferior); S, sella; LE sup-LE inf: (mm), line that goes from the tip of the nose to the (Me) point should be paralell to the upper and lower lip.

individuals. Furthermore, it is noteworthy that although at present most NOG mutations reported have been associated with symphalangism, bone problems, upper and lower limb joints, it also, presents face anomalies, such as hemicylindrical nose, thin vermilion of the upper lip, and asymmetric mouth and other additional characteristics. ${ }^{37}$ In the present 
A
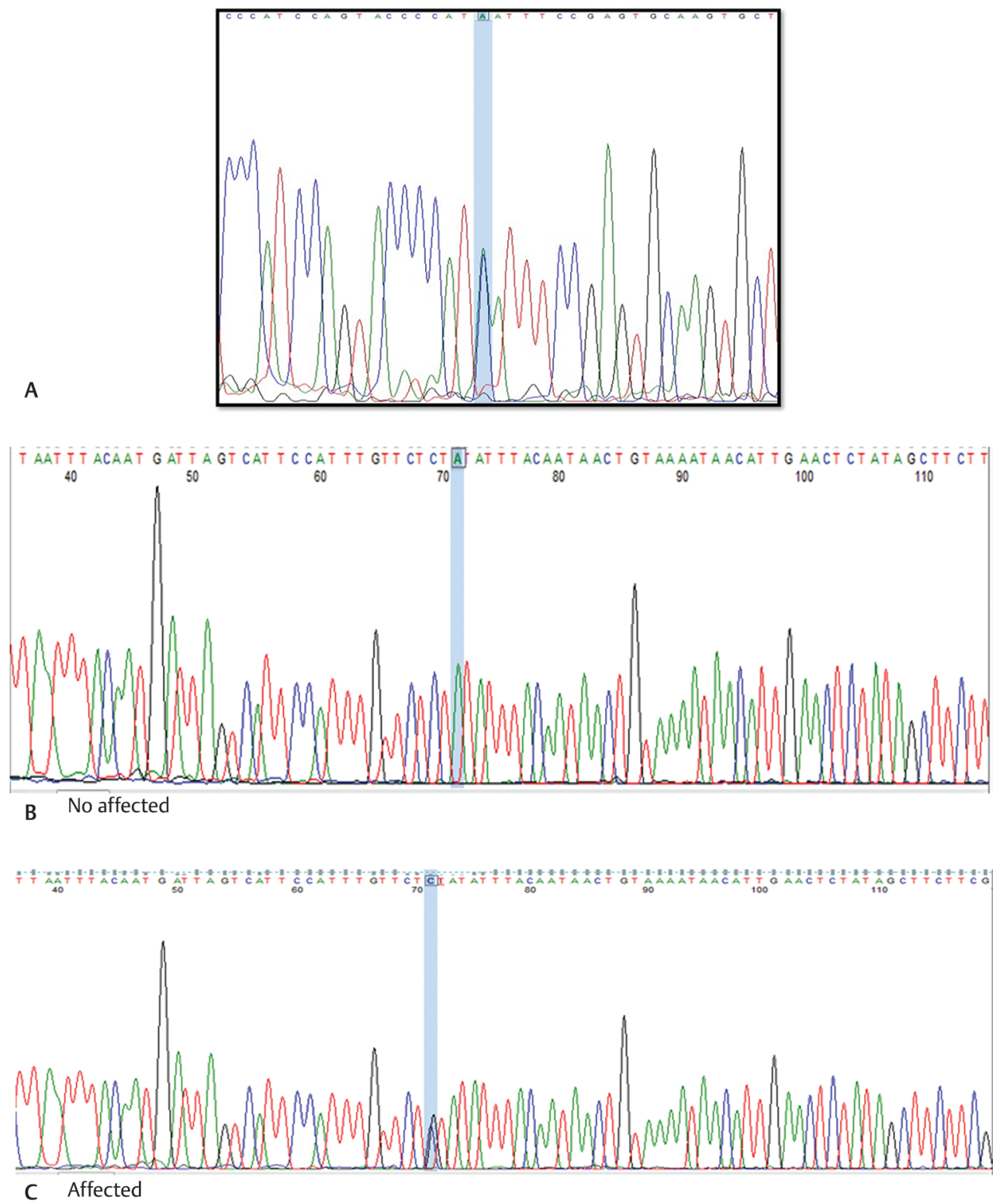

Fig. 3 (A) NOG gene change in the coding region from a Cytosine to an Adenine at nucleotide 672 (c.672C > A). This change found in NOG exon 1 gene was present in individuals III:2; III:1 and II-3 of Family 1, all affected with mandibular micrognathism. (B) NOG gene DNA sequencing profile in Family 2. Chromatogram of I-1 (control upper side) and Chromatogram of II-4 affected proband (lower side), which illustrates presence of heterozygous 567 G/C (SNP RS116716909) 3' UTR, polymorphism reported by Zody et al. ${ }^{32}$ All the affected with mandibular micrognathism presented this change. NOG, noggin gene.

study, this variant was identified, mandibular micrognathism was present, in addition to upper lip forward, facial asymmetry, convex profile, and low implantation of the outer ear were present without any evidence of hearing loss among others (-Table 5).

Upon genetic examination, the patients with this variant did not manifest any syndromic problem nor any evidence of characteristics affecting hand joints, knees or feet, or bone deformities. In line with that reported by Moffet et al, ${ }^{39}$ who didn't find a significant association between NOG gene polymorphisms and bone phenotypes including osteoporosis.

The most mutations reported for NOG associated with symphalangism and bone alterations tend to be localized in regions affecting NOG's capacity to bind to BMPs receptors, thus presenting an ample spectrum of phenotypes. ${ }^{37,38}$ The polymorphic variant c.567G > C (rs116716909) presented in the individuals of family 2 of this study was located in the 3' UTR 567 nucleotides downstream of the stop codon $^{32}$ ( - Fig. 3B), and it is possible its location resulted in certain phenotypic characteristics, such as mandibular micrognathism, supporting the hypothesis proposed by Sha et $\mathrm{al}^{35}$ where they suggested that certain phenotypes are associated with the exact localization of the mutation. It is probable for these individuals that the heterozygous sequence change exerted a very subtle effect on NOG gene (haploinsufficiency), slightly altering BMP signal modulation. Hence, they presented mandibular micrognathism without the accompanying severe bone characteristics. 
In the present study, we also report a new heterozygous variant, consisting of a change from a cytosine to an adenine at nucleotide 672 (c.672C > A) in the coding region of NOG gene (-Fig. $\mathbf{3 A}$ ) and was observed in three members of the family 1 (mother, daughter, and cousin) affected with mandibular micrognathism. The phenotypic characteristics of the members that presented this variant are depicted in - Table 4. These were similar to the characteristics present by the members of the family 2 , who present the c.567G > C (rs116716909) variant.

Although this new variant appears to be silent (change from one isoleucine to another isoleucine in the protein), the literature reports that these mutations may not be as silent as believed based on availability of transfer RNA (RNAt). If it exists in a small quantity to transport amino acids, translation is delayed and slows down which may result in less expression of the particular gene that contains the silent mutation in its coding region. Additionally, it seems that at any given time due to the delay in receiving the amino acid, the ribosome could terminate the translation prematurely. ${ }^{40,41}$ This could be one of the reasons why this phenotype may occur in this family, but protein functional studies with this variant must be performed.

Mother, daughter, and cousin affected with the new variant didn't evidence any osseous problems in knees, hands, or feet joints. In addition, upon clinical-genetic examination, they didn't present an associated syndrome, in line with reports in the literature, where substitution variants in the NOG gene, such as c_385C > A (rs117249328), ${ }^{32}$ c._520G. A (N/A), and c._73G4A(N/A) 35 didn't present any osseous characteristics, such as osteoporosis, symphalangism, or decreased mineralization. ${ }^{42}$

On the other hand, to date, there are no reports associated to DNA methylation pattern alterations with mandibular disorders. The present study is a first approximation on NOG gene methylation patterns, with the objective of determining a possible cause for mandibular micrognathism in these patients that would be unrelated to DNA sequence alterations. However, in the sample studied no $\mathrm{CH}_{3}$ groups were observed in the promoter region, which could suggest that no alterations in NOG promoter DNA methylation patterns in these studied individuals that could be associated with mandibular alterations and that other epigenetic factors could modulate mandibular growth. Studies are necessary that provide more evidence in this regard.

\section{Conclusion}

The results of this study showed the presence of two variants of the NOG gene and their phenotypic characteristics in patients with mandibular micrognathism, representing an important step toward the understanding of the genetic component of this disorder, and indicating the possible involvement of this gene in isolated mandibular micrognathism. However, it would be recommended for the respective tests to be performed for the diagnosis of mandibular micrognathism in patients with bone alterations, among these symphalangism, to determine if in these patients this alteration also manifests.

On the other hand, the fact that these two different variants present in the NOG gene may be involved in the same phenotype with similar characteristics in two different families could suggest the existence of allelic heterogeneity which is attributable to genetic and/or environmental factors. This first study of DNA methylation in the NOG gene in this group of individuals with mandibular micrognathism showed the absence of methyl groups in NOG's gene promoter region in blood cells, which could correspond to a pleiotropic role of NOG, since this gene participates in transforming growth factor (TGF)- $\beta$ superfamily signaling inactivating BMP-4 and acting as a morphogen responsible of gradient expression in the differentiation of tissues during embryological development and tissue homeostasis.

The fact of not having found methylated sites in the NOG promoter region in this population under study can give us an approximation that the cause of this phenotype does not seem to be related to the inhibition of gene expression due to the presence of methylated sites in the promoter region, and that other environmental factors could be involved.

Finally, the studies of the presence of NOG gene variants could help predict alterations, such as skeletal class II in families, which traditionally has been estimated from the correlation between the phenotypes of parents and their offspring or the comparison of phenotypes between monozygotic twin pairs (MZ) and dizygotic (DZ). It is essential that dental professionals, especially orthodontists, consider the genetic factors that are influencing more frequent in the developmental alterations in the population and how this will contribute to the diagnostic and successful management of their patients, including new therapies, where the possibility of gene therapy can be contemplated in the near future.

\section{Funding}

This project was financed by Pontificia Javeriana University, grant no: 4397 and 9217.

\section{Conflict of Interest}

None declared.

\section{Acknowledgment}

Authors would like to thank Pontificia Javeriana University for their support.

\section{References}

1 Mossey PA, Modell B, Epidemiology of oral cleft: an international perspective. In: Wyszynski DF, ed. Cleft lip and palate. From Origin to Treatment. New York, NY: Oxford University Press; 2002

2 Holder-Espinasse $\mathrm{M}$, Abadie $\mathrm{V}$, Cormier-Daire $\mathrm{V}$, et al. Pierre Robin sequence: a series of 117 consecutive cases. J Pediatr 2001;139(4):588-590

3 Pruzinsky T. Social and psychological effects of major craniofacial deformity. Cleft Palate Craniofac J 1992;29(6):578-584, discussion 570 
4 Chigurupati R, Massie J, Dargaville P, Heggie A. Internal mandibular distraction to relieve airway obstruction in infants and young children with micrognathia. Pediatr Pulmonol 2004;37(3):230-235

5 Martínez-Plaza A, Martínez-Lara I, García-Medina B, Fernández- Valadés R. Distracción ósea: tratamiento de la apnea obstructiva en neonatos con micrognatia. Rev Esp Cir Oral Maxilofac 2011;33(2):67-74

6 Yu S, Tang Q, Xie M, et al. Circadian BMAL1 regulates mandibular condyle development by hedgehog pathway. Cell Prolif 2020;53(1):e12727

7 Mina M, Wang YH, Ivanisevic AM, Upholt WB, Rodgers B. Region- and stage-specific effects of FGFs and BMPs in chick mandibular morphogenesis. Dev Dyn 2002;223(3):333-352

8 Tucker AS, Yamada G, Grigoriou M, Pachnis V, Sharpe PT. Fgf-8 determines rostral-caudal polarity in the first branchial arch. Development 1999;126(1):51-61

9 Shigetani Y, Nobusada Y, Kuratani S. Ectodermally derived FGF8 defines the maxillomandibular region in the early chick embryo: epithelial-mesenchymal interactions in the specification of the craniofacial ectomesenchyme. Dev Biol 2000;228(1):73-85

10 Ferguson CA, Tucker AS, Sharpe PT. Temporospatial cell interactions regulating mandibular and maxillary arch patterning. Development 2000;127(2):403-412

11 Ekanayake S, Hall BK. The in vivo and in vitro effects of bone morphogenetic protein- 2 on the development of the chick mandible. Int J Dev Biol 1997;41(1):67-81

12 Kanzler B, Foreman RK, Labosky PA, Mallo M. BMP signaling is essential for development of skeletogenic and neurogenic cranial neural crest. Development 2000;127(5):1095-1104

13 Bonilla-Claudio M, Wang J, Bai Y, Klysik E, Selever J, Martin JF. Bmp signaling regulates a dose-dependent transcriptional program to control facial skeletal development. Development 2012;139(4):709-719

14 Brunet LJ, McMahon JA, McMahon AP, Harland RM. Noggin, cartilage morphogenesis, and joint formation in the mammalian skeleton. Science 1998;280(5368) :1455-1457

15 McMahon JA, Takada S, Zimmerman LB, Fan CM, Harland RM, McMahon AP. Noggin-mediated antagonism of BMP signaling is required for growth and patterning of the neural tube and somite. Genes Dev 1998;12(10):1438-1452

16 Zimmerman LB, De Jesús-Escobar JM, Harland RM. The Spemann organizer signal noggin binds and inactivates bone morphogenetic protein 4. Cell 1996;86(4):599-606

17 Valenzuela DM, Economides AN, Rojas E, et al. Identification of mammalian noggin and its expression in the adult nervous system. J Neurosci 1995;15(9):6077-6084

18 Potti TA, Petty EM, Lesperance MM. A comprehensive review of reported heritable noggin-associated syndromes and proposed clinical utility of one broadly inclusive diagnostic term: NOG-related-symphalangism spectrum disorder (NOG-SSD) Hum Mutat 2011;32(8):877-886

19 Gong Y, Krakow D, Marcelino J, et al. Heterozygous mutations in the gene encoding noggin affect human joint morphogenesis. Nat Genet 1999;21(3):302-304

20 Masuda S, Namba $\mathrm{K}$, Mutai $\mathrm{H}$, et al. A mutation in the heparin-binding site of noggin as a novel mechanism of proximal symphalangism and conductive hearing loss. Biochem Biophys Res Commun 2014;447(3):496-502

21 Sémonin O, Fontaine K, Daviaud C, Ayuso C, Lucotte G. Identification of three novel mutations of the noggin gene in patients with fibrodysplasia ossificans progressiva. Am J Med Genet 2001;102(4):314-317

22 Anderson RM, Lawrence AR, Stottmann RW, Bachiller D, Klingensmith J. Chordin and noggin promote organizing centers of forebrain development in the mouse. Development 2002;129(21):4975-4987

23 Gutiérrez SJ, Gómez M, Rey JA, Ochoa M, Gutiérrez SM, Prieto JC. Polymorphisms of the noggin gene and mandibular micrognathia: a first approximation. Acta Odontol Latinoam 2010;23(1):13-19

24 Song T, Shi J, Guo Q et al. Association between NOGGIN and SPRY2 polymorphisms and nonsyndromic cleft lip with or without cleft palate. Am J Med Genet A 2015;167A(1):137-141

25 Mangold E, Ludwig KU, Birnbaum S, et al. Genome-wide association study identifies two susceptibility loci for nonsyndromic cleft lip with or without cleft palate. Nat Genet 2010;42(1):24-26

26 Setó-Salvia N, Stanier P. Genetics of cleft lip and/or cleft palate: association with other common anomalies. Eur J Med Genet 2014;57(8):381-393

27 Gudbjartsson DF, Walters GB, Thorleifsson G, et al. Many sequence variants affecting diversity of adult human height. Nat Genet 2008;40(5):609-615

28 Nimmagadda S, Buchtová M, Fu K, et al. Identification and functional analysis of novel facial patterning genes in the duplicated beak chicken embryo. Dev Biol 2015;407(2):275-288

29 Garrick D, Fiering S, Martin DI, Whitelaw E. Repeat-induced gene silencing in mammals. Nat Genet 1998;18(1):56-59

$30 \mathrm{Xu}$ J, Wang AH, Oses-Prieto J, et al. Arginine methylation initiates BMP-induced Smad signaling. Mol Cell 2013;51(1):5-19

31 Miller SA, Dykes DD, Polesky HF. A simple salting out procedure for extracting DNA from human nucleated cells. Nucleic Acids Res 1988;16(3):1215

32 Zody MC, Garber M, Adams DJ, et al. DNA sequence of human chromosome 17 and analysis of rearrangement in the human lineage. Nature 2006;440(7087):1045-1049

33 Marcelino J, Sciortino CM, Romero MF, et al. Human disease-causing NOG missense mutations: effects on noggin secretion, dimer formation, and bone morphogenetic protein binding. Proc Natl Acad Sci U S A 2001;98(20):11353-11358

34 Takano K, Ogasawara N, Matsunaga T, et al. A novel nonsense mutation in the NOG gene causes familial NOG-related symphalangism spectrum disorder. Hum Genome Var 2016;3:16023

35 Sha Y, Ma D, Zhang N, Wei X, Liu W, Wang X. Novel NOG (p.P42S) mutation causes proximal symphalangism in a four-generation Chinese family. BMC Med Genet 2019;20(1):133

36 Liu WD, Feng XL, Ren CP, et al. Critical role of Cys168 in noggin protein's biological function. Acta Biochim Biophys Sin (Shanghai) 2005;37(3):181-185

37 Higashi K, Inoue S. Conductive deafness, symphalangism, and facial abnormalities: the WL syndrome in a Japanese family. Am J Med Genet 1983;16(1):105-109

38 Dąbrowska M, Dąbrowski P, Tabarkiewicz J. Fibrodysplasia Ossificans Progressiva - a presentation of cases and literature review. European J of Clin and Experim Med. 2019;2:184-191

39 Moffett SP, Dillon KA, Yerges LM, et al. Identification and association analysis of single nucleotide polymorphisms in the human noggin (NOG) gene and osteoporosis phenotypes. Bone 2009;44(5):999-1002

40 Angov E. Codon usage: nature's roadmap to expression and folding of proteins. Biotechnol J 2011;6(6):650-659

41 Alberts B, Johnson A, Lewis J, Raff M, Roberts K, Walter P.W Molecular Biology of the Cell. 4th ed. New York, NY: Garland Science; 2007

42 Yerges LM, Klei L, Cauley JA, et al. High-density association study of 383 candidate genes for volumetric BMD at the femoral neck and lumbar spine among older men. J Bone Miner Res 2009;24(12):2039-2049 